\title{
INDUCTION AND TIMING OF SINGLE AND MULTIPLE OVULATIONS IN THE SQUIRREL MONKEY (SAIMIRI SCIUREUS)
}

\author{
W. R. DUKELOW* \\ Department of Biochemistry, University of Georgia, \\ Athens, Georgia 30601, U.S.A.
}

(Received 10th Fuly 1969)

\begin{abstract}
Summary. Fifty-six squirrel monkeys were studied to develop means of accurate ovulation induction. Ovaries were exposed to determine ovulation time. Pre-treatment with progesterone to suppress spontaneous ovulation ( $5 \mathrm{mg}$ daily for 5 days) was followed by: (a) no FSH, (b) $1 \mathrm{mg}$ FSH, (c) human menopausal gonadotrophin (HMG), equivalent to 75 i.u. FSH, or (d) 200 i.u. pregnant mare's serum gonadotrophin (PMSG), each for 4 additional days. Ovulation was induced in $43 \%$ of the animals with either 250 or 500 i.u. of human chorionic gonadotrophin (HCG) administered intravenously (i.v.) or intramuscularly (i.m.). Four double ovulations were observed, the others were single ovulations. No follicular development occurred in animals which did not receive an exogenous source of FSH. FSH was superior to HMG and PMSG in its ability to promote follicular growth. Nearly twice as many animals ovulated after 500 i.u. HGG than with 250 i.u. Injection of the HCG i.v. or i.m. did not affect the percentage of animals that ovulated but greater variation in the time of ovulation was noted with i.v. injections.
\end{abstract}

\section{INTRODUCTION}

Accurate timing of ovulation is a prerequisite for definitive studies of the early stages of fertilization in any species. The period during which the ovum can be fertilized, limited to a few hours in most species, is of critical importance for studies on sperm capacitation and in vitro fertilization (Dukelow, Chernoff \& Williams, 1967). In view of this fact and of the importance of the non-human primate in biomedical research on reproduction and fertility control, we have developed techniques for inducing single or multiple ovulations at a predictable time in the squirrel monkey.

Ovulation has been induced in other non-human primates, chiefly in Macaca mulatta. As early as 1935, Hisaw, Greep \& Fevold, using crude ovine anterior pituitary extracts, reported ovulation induction in three out of four macaques. Hartman (1938) reported a total of seven ovulations out of 104

* Present address: Endocrine Research Unit, Center for Laboratory Animal Resources, Michigan State University, East Lansing, Michigan 48823, U.S.A. 
cycles in anovulatory adult rhesus monkeys. In 1942, he reported an additional six ovulations out of forty-six cycles. Pfeiffer (1950) attempted to prevent ovulation in rhesus monkeys with $0.5 \mathrm{mg}$ of progesterone daily from the 10th to the 14th day of the cycle. Four ovulations were obtained from eleven monkeys after the end of treatment.

Most of the work on the induction of ovulation in non-human primates has been carried out by van Wagenen and her colleagues and has been recently summarized (van Wagenen, 1968). Beginning in 1935, she unsuccessfully attempted to induce ovulation in macaques with pregnant mare's serum gonadotrophin (PMSG) (van Wagenen \& Cole, 1938). Later work with purified FSH and interstitial cell stimulating hormone (ICSH) of ovine origin was ineffective in inducing ovulation. In 1956, Knobil, Morse \& Greep reported the importance of species-specificity in some primate pituitary hormones. This led to the important observation (van Wagenen \& Simpson, 1957a, b; Simpson \& van Wagenen, 1957) that in a significant number of cases, multiple ovulation was obtained with gonadotrophins of primate origin. Subsequently, Knobil, Kostyo \& Greep (1959) induced ovulation in hypophysectomized macaques by treatment with porcine FSH and human chorionic gonadotrophin (HGG).

In the intervening years, various ovulation-inducing agents have been studied for their effect on ovulation in rhesus monkeys. Dede \& Plentl (1966) used Pergonal (human menopausal gonadotrophin, HMG) injections for 8 to 10 days followed by 2-day injections of HMG and HCG. The animals were then mated or artificially inseminated and pregnancies were obtained.

Wan \& Balin (1969), using HMG/HGG, clomiphene citrate and DL-18-methyl oestriol to induce ovulation in macaques, were successful in $60 \%, 59 \%$, and $32 \%$ of the treated cycles, respectively. They were also successful in obtaining high incidences of single ovulations in contrast to Simpson \& van Wagenen (1962), who reported multiple ovulations on each ovary.

Bennett $(1967 \mathrm{a}, \mathrm{b})$ induced multiple ovulation in the squirrel monkey with various regimens of PMSG and HCG. He demonstrated that ova can be recovered from the oviducts and suggested that, probably because of the elevated level of oestrogen from the ovary, tubal transport could be speeded up by the high level of PMSG employed. Bennett began injections without reference to the stage of the cycle. The duration of the oestrous cycle in Saimiri is reported to range from 6.0 to 9.5 days by Rosenblum, Nathan, Nelson \& Kaufman (1967) and from 23 to 69 days by Denniston (1964).

So far, no attempt appears to have been made to induce ovulation with the specific objective of timing ovulation accurately and of recovering the ovum within the period during which it can be fertilized.

\section{MATERIALS AND METHOD}

Forty-six mature squirrel monkeys (Saimiri sciureus) of the Brazilian and Peruvian types (Hill, 1960) were housed in wire cages, two to three animals per cage. All monkeys were injected intramuscularly (i.m.) with $5 \mathrm{mg}$ of progesterone dissolved in $0.25 \mathrm{ml}$ of cottonseed oil daily for 5 days to suppress spontaneous ovulation. After a 4-day lapse following progesterone treatment, 
six animals were injected intravenously (i.v.) with either 250 or 500 i.u. of HCG to induce ovulation in order to ascertain whether this treatment alone would induce follicular growth and ovulation. The ovaries were exposed by a midline incision 10 to $12 \mathrm{hr}$ later and examined for evidence of follicular growth and ovulation.

Three sources of FSH were studied in order to determine their potency for initiating follicular growth. (1) FSH-P (Armour-Baldwin Laboratories), a lyophilized product obtained from the pituitaries of domestic animals, was administered subcutaneously (s.c.) daily for 4 days after progesterone pretreatment. (2) HMG (Ortho Research Foundation, Lot no. 2282) containing 75 i.u. of FsH and 25 i.u. LH was injected s.c. for either 2 or 4 days after cessation of the progesterone pre-treatment. (3) PMsG (Gonadogen, Upjohn Company) was injected daily in doses of 200 i.u. for 4 days.

TABLE 1

EFFECT OF VARIOUS SOURCES OF FSH ON OVULATION

\begin{tabular}{l|c|c|c|c}
\hline \multicolumn{1}{c|}{ Treatment } & $\begin{array}{c}\text { No. of } \\
\text { animals }\end{array}$ & $\begin{array}{c}\text { Mean no. ovulation } \\
\text { points/animal }\end{array}$ & $\begin{array}{c}\% \text { animals } \\
\text { ovulating }\end{array}$ & $\begin{array}{c}\text { Mean no. of ripe } \\
\text { follicles/animal }\end{array}$ \\
\hline Progesterone only, & 6 & 0 & 0 & 0 \\
no FSH source & 23 & $1 \cdot 3$ & $56 \cdot 6$ & $\overline{5 \cdot 3}$ \\
Progesterone, FSH-P & 5 & $1 \cdot 0$ & $20 \cdot 0$ & $1 \cdot 7$ \\
Progesterone, HMG & 12 & $1 \cdot 0$ & $25 \cdot 0$ & \\
Progesterone, PMSG & & & \\
\hline
\end{tabular}

Only HCG was used to induce ovulation. This was administered at a level of either 250 or 500 i.u. in physiological saline, either i.v. or i.m. After midline exposure of the ovaries, the animals were kept under anaesthesia for $4 \mathrm{hr}$. At hourly intervals, the ovaries were examined and photographed to ascertain the time of ovulation.

In an effort to duplicate the superovulation obtained by Bennett (1967a), a 9-day course of injections was administered to four animals without the progesterone pre-treatment: 200 i.u. of PMSG were given for 5 days, followed by 4 days of PMSG and 500 i.u. of HCG. The ovaries were examined on Day 11 for ovulation and the oviducts were removed and flushed for ovum recovery. To determine if ovulation occurred after the surgical procedure, ten additional animals were subjected to the progesterone-FSH-P-HCG (500 i.u.) procedure and examined $40 \mathrm{hr}$ after the last injection.

Parts of this work relating to FsH-induced ovulation have been published in a preliminary report (Dukelow, Guilloud, Willcox \& Cline, 1969).

\section{RESULTS}

Attempts at inducing follicular growth and ovulation following pre-treatment with progesterone were unsuccessful (Table 1); no follicular development was noted in any of the six animals and the ovaries were quiescent (Pl. 1, Fig. 1).

Out of a total of forty observations where an exogenous source of FSH was used, seventeen $(42.5 \%)$ animals ovulated with a total of twenty-one ovulation 
points. Single ovulations were noted in $76.4 \%$ and double ovulations in $23.6 \%$. No higher rate of ovulation occurred except in those animals superovulated by the Bennett technique. FSH-P was the most effective treatment in terms of ovulation points per animal and in the percentage of ovulations in response to HCG injection. HMG stimulated a high incidence of follicular development (mean of 5.3 follicles per animal), but the incidence of ovulation was only $20 \%$. Similarly, PMSG administered once daily for 4 days did not stimulate a high incidence of follicular growth, and only $25 \%$ of these animals ovulated.

Five hundred i.u. of HCG were superior to 250 i.u. in inducing ovulation but the percentage of ovulation from i.m. and i.v. administration did not differ

TABle 2

THE EFFECT OF THE AMOUNT AND TYPE OF HCG INJECTION ON OVULATION

\begin{tabular}{|c|c|c|c|c|c|}
\hline Treatment & $\begin{array}{l}\text { No. of } \\
\text { animals }\end{array}$ & $\begin{array}{c}\text { Mean no. of } \\
\text { ovulation points }\end{array}$ & $\begin{array}{l}\% \text { animals } \\
\text { ovulating }\end{array}$ & $\begin{array}{c}\text { Time range } \\
\text { after } H C G(\text { hr: } \min )\end{array}$ & $\begin{array}{l}\text { Minimum time } \\
\text { between } H C G \text { and } \\
\text { ovulation (hr:min) }\end{array}$ \\
\hline $\begin{array}{l}250 \text { i.u. } \\
500 \text { i.u. }\end{array}$ & $\begin{array}{l}15 \\
25\end{array}$ & $\begin{array}{l}1 \cdot 25 \\
1 \cdot 23\end{array}$ & $\begin{array}{l}26 \cdot 7 \\
52 \cdot 1\end{array}$ & $\begin{array}{l}<6: 31 \text { to } 11: 25 \\
<7: 47 \text { to } 11: 54\end{array}$ & $\begin{array}{l}4: 54 \\
3: 07\end{array}$ \\
\hline $\begin{array}{l}\text { i.m. injection } \\
\text { i.v. injection }\end{array}$ & $\begin{array}{l}10 \\
30\end{array}$ & $\begin{array}{l}1.00 \\
1.31\end{array}$ & $\begin{array}{l}40 \cdot 0 \\
43 \cdot 4\end{array}$ & $\begin{array}{r}10: 13 \text { to } 11: 54 \\
<6: 31 \text { to } 11: 40\end{array}$ & $\begin{array}{l}1: 40 \\
5: 09\end{array}$ \\
\hline
\end{tabular}

TABLE 3

TIMED OVULATIONS IN SAIMIRI (HR:MIN POSTHCG)

\begin{tabular}{c|c}
\hline \multicolumn{2}{c}{ Type of injection } \\
\hline i.v. & i.m. \\
\hline $11: 40$ & $11: 54$ \\
$6: 57$ & $11: 09$ \\
$7: 10$ & $10: 13$ \\
$10: 53$ & $11: 25$ \\
$8: 34$ & \\
$8: 20$ & \\
\hline
\end{tabular}

significantly (Table 2). The interaction between the route of injection and amount of HCG was not statistically significant and, therefore, the data for route and dose are pooled separately in Table 2 . The ovulation points were distinct, red protruberances on the surface of the ovary (Pl. I, Fig. 2).

Ovulation occurred during the surgical procedure in ten animals and the time from HCG injection to ovulation was calculated (Table 3). For three of them, this was a second ovulation, the first having occurred before surgery. Of the seventeen monkeys ovulating, ten ovulated before surgery, some earlier than $6 \mathrm{hr} 32 \mathrm{~min}$ after HCG injections. All of these early ovulations occurred in animals receiving an i.v. injection of HCG. The time of ovulation in animals 
PLATE 1
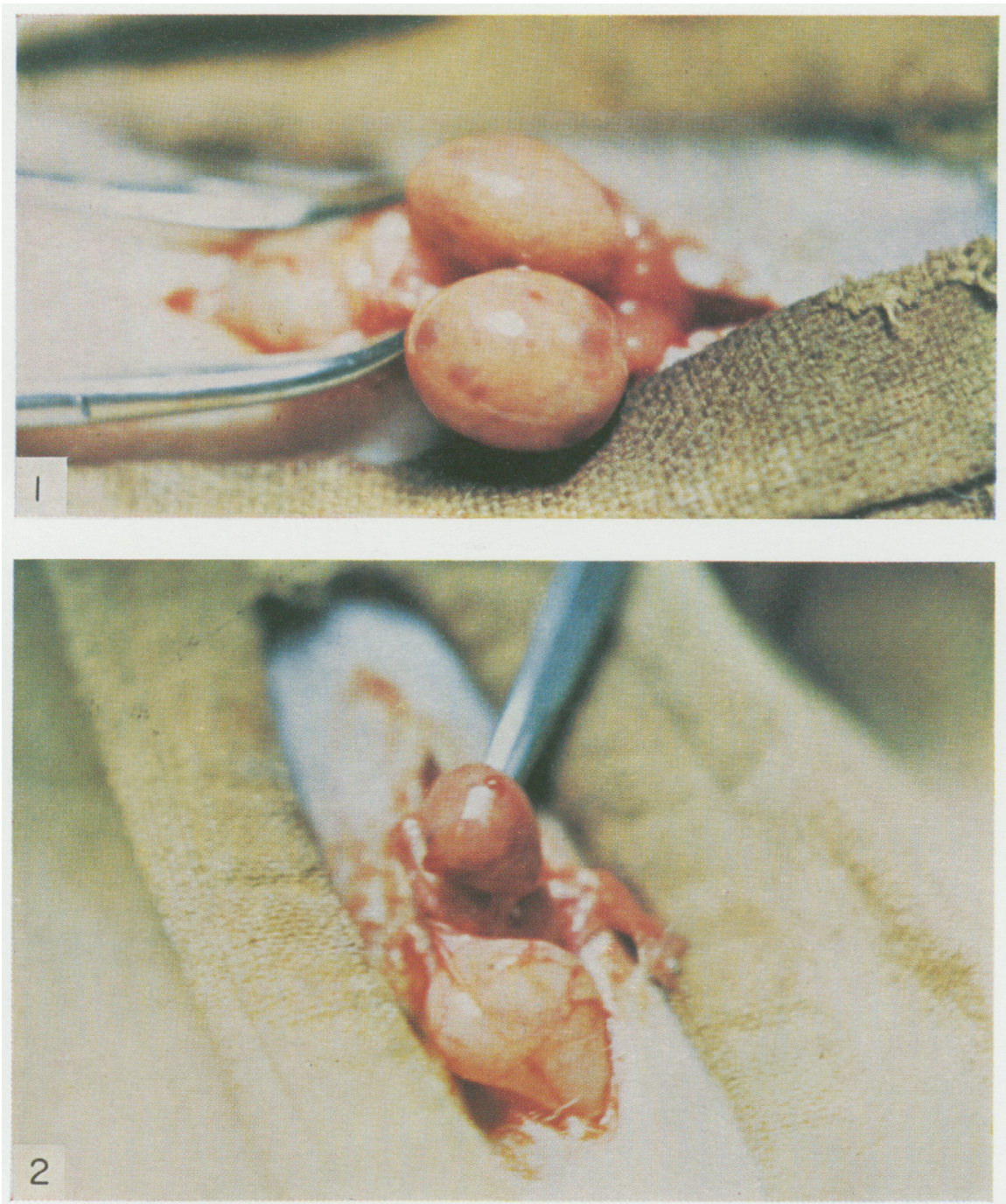

Fic. 1. Quiescent ovaries of Saimiri treated with progesterone alone (no FSH source).

Fic. 2. Two fresh ovulation points on the left ovary of Saimiri. 
receiving an i.m. injection of HCG ranged from $10 \mathrm{hr} 13 \mathrm{~min}$ to $11 \mathrm{hr} 54 \mathrm{~min}$. The greatest variability in ovulation time occurred with i.v. injections, with a minimum variability of $5 \mathrm{hr} 9 \mathrm{~min}$ compared to $1 \mathrm{hr} 40 \mathrm{~min}$ with i.m. injection. In four animals, double ovulation was observed (all with HCG administered intravenously) and the minimum difference in time between first and second ovulation was calculated (Table 4). In all cases, the first ovulation occurred before surgery. The highest minimum difference between first and second ovulations was $2 \mathrm{hr} 38 \mathrm{~min}$.

TABLE 4

TIME OF DOUBLE OVULATIONS

\begin{tabular}{c|c}
\hline Time $($ hr:min $)$ & $\begin{array}{c}\text { Minimum difference } \\
\text { between ovulations }(\text { hr:min })\end{array}$ \\
\hline Both $<11: 16$ & $?$ \\
$<9: 05$ and $11: 40$ & $2: 35$ \\
$<6: 31$ and $6: 57$ & $0: 26$ \\
$<8: 42$ and $10: 53$ & $2: 38$ \\
\hline
\end{tabular}

All i.v. injections.

TABLE 5

OVULATION DIFFERENCES BETWEEN SAIMIRI OF BRAZILIAN OR PERUVIAN ORIGIN

\begin{tabular}{c|c|c|c|c|c}
\hline $\begin{array}{c}\text { Saimiri } \\
\text { type }\end{array}$ & $\begin{array}{c}\text { No. of } \\
\text { animals }\end{array}$ & $\begin{array}{c}\text { Mean no. of } \\
\text { ovulation points }\end{array}$ & $\begin{array}{c}\% \text { animals } \\
\text { ovulating }\end{array}$ & $\begin{array}{c}\text { Time range } \\
\text { after HCG (hr:min) }\end{array}$ & $\begin{array}{c}\text { Minimum time } \\
\text { between HCG and } \\
\text { ovulation (hr :min) }\end{array}$ \\
\hline Brazilian & 28 & $1 \cdot 23$ & 46.4 & $<6: 31$ to $11: 54$ & $5: 23$ \\
Peruvian & 12 & 1.25 & 33.3 & $<8: 05$ to $10: 53$ & $2: 48$ \\
\hline
\end{tabular}

The mean number of ovulation points, the percentage of animals ovulating, and the range in time of ovulation did not differ significantly in Brazilian- and Peruvian-type squirrel monkeys (Table 5).

When the superovulation technique of Bennett (5 days PMSG, 4 days PMSGHCG) was performed on four animals, a total of nineteen ovulation points ranging from two to seven (or an average of 4.75 per animal) was observed. A few ova were recovered by flushing the oviduct but because of technical problems, the number of ova recovered is not considered relevant to this study.

Of the ten animals observed for ovulation $40 \mathrm{hr}$ after HCG, six had ovulated with an average of 1.9 ovulation points per animal, indicating that while ova recovery at 11 to $12 \mathrm{hr}$ after HCG will yield freshly ovulated ova, ovulation can occur later.

\section{DISGUSSION}

The squirrel monkey, now widely used in the research laboratory because of size, cost, and adaptability to surgical procedures, ranks second only to the rhesus in popularity. The successful induction of consistent ovulation in this species has proved the squirrel monkey to be suitable for studies on the period 
of progestation, artificial inhibition of ovulation, and on primate sperm capacitation (Dukelow \& Chernoff, 1969) and in vitro fertilization.

The present study demonstrates that a reasonable level of ovulation $(56 \%)$ can be attained in the squirrel monkey with a regimen of 5 days of progesterone followed by 4 days of FSH and an injection of 500 i.u. of HCG. HMG caused an adequate number of follicles per animal to develop but ovulation was induced only in relatively few animals. Similarly PMSG, administered only once daily for 4 days, was not sufficient to cause large numbers of follicles to develop. If numerous follicles and superovulation are desired, PMSG must be administered twice daily over a 9-day period and combined with 250 to 500 i.u. of HGG during the last 4 days. Under this regimen, superovulation occurred and thus confirmed the work of Bennett (1967a) who obtained an average of 5.3 ovulation points per ovary in two animals.

As one would expect, ovulation occurs more rapidly with i.v. injection of HCG; moreover, the variability of the time of ovulation is much greater. For the accurate timing of ovulation and the higher probability of obtaining a freshly ovulated ovum ( 1 to $2 \mathrm{hr}$ old), i.m. injections should be used followed by surgical recovery 11 to $12 \mathrm{hr}$ later.

The above regimen will yield single ovulations in about $75 \%$ of the cases, with double ovulations occurring in the rest. Multiple ovulations are of greater importance to experimental researchers than to observers of the animal in the wild state since twinning is quite rare in this species (Napier \& Napier, 1967). The interesting variation in time between ovulations (up to $2 \mathrm{hr} 38 \mathrm{~min}$ ) corresponds to the report of Harper (1961) who demonstrated that ovulation can be spread over a period of nearly $4 \mathrm{hr}$ in the rabbit.

\section{ACKNOWLEDGMENTS}

I am grateful to my associates, Dr N. B. Guilloud, Mr J. E. Willcox, Mrs E. M. Gline, and Mr. L. J. Patrick, for technical assistance during these trials and to my colleague, Dr W. L. Williams, for reading and criticizing the manuscript. Thanks are expressed to Dr R. P. Blye, Ortho Research Foundation, for graciously providing the HMG used and to Dr J. Bennett, Syntex Research Gorporation, for advice on the technical aspects of the project. This work was supported by grants from the Lalor Foundation and National Institutes of Health, and a research contract (No. 69-2095) from the National Institute of Child Health and Human Development, National Institutes of Health.

\section{REFERENCES}

Bennetr, J. P. (1967a) The induction of ovulation in the squirrel monkey (Saimiri sciureus) with pregnant mares serum (PMS) and human chorionic gonadotrophin (HCG). F. Reprod. Fert. 13, 357.

Bennetr, J. P. (1967b) Artificial insemination of the squirrel monkey. 7. Endocr. 37, 473.

Dede, J. A. \& Plentr, A. A. (1966) Induced ovulation and artificial insemination in a rhesus colony. Fert. Steril. 17, 757.

Denniston, R. H. (1964) Notes on the vaginal cornification cycle of captive squirrel monkeys. $\mathcal{F}$. Mammal. 46, 471.

Dukelow, W. R. \& Chernoff, H. N. (1969) Primate sperm survival and capacitation in a foreign uterine environment. Am. F. Physiol. 216, 682.

Dukelow, W. R., Ghernoff, H. N. \& Williams, W. L. (1967) Fertilizable life of the rabbit ovum relative to sperm capacitation. Am. F. Physiol. 213, 1397. 
Dukelow, W. R., Guilloud, N. B., Willcox, J. E. \& Cline, E. M. (1969) Ovulation induction in the squirrel monkey. Proc. 20th Ann. Meeting, Amer. Assoc. Lab. Animal Science, Oct. 13-17, Dallas. (in press).

HARPer, M. J. K. (1961) The time of ovulation in the rabbit following the injection of luteinizing hormone. 7. Endocr. 22, 147.

Hartman, G. G. (1938) The use of gonadotropic hormones in the adult rhesus monkey. Bull. Fohns Hopkins Hosp. 63, 351 .

Hartman, C. G. (1942) Further attempts to cause ovulation by means of gonadotropes in the adult rhesus monkey. Contr. Embryol. 30, 113.

Hilc, W. C. O. (1960) Primates. In: Comparative Anatomy and Taxonomy, Vol. IV, Part A, pp 250322. Edinburgh University Press.

Hisaw, F. L., Greep, R. O. \& Fevold, H. O. (1935) Experimental ovulation of Macacus rhesus monkeys. Anat. Rec. 61, Suppl. p. 24.

Knoril, E., Kostyo, J. L. \& Greep, R. O. (1959) Production of ovulation in the hypophysectomized rhesus monkey. Endocrinology, 65, 487.

Knobil, E., Morse, A. \& Greep, R. O. (1956) The effects of beef and monkey pituitary growth hormone on the costochondral junction in the rypophysectomized rhesus monkey. Anat. Rec. 124, 320.

Napier, J. R. \& Napier, P. H. (1967) A handbook of living primates, p. 313. Academic Press, New York.

Pfeiffer, C. A. (1950) Effects of progesterone upon ovulation in the rhesus monkey. Proc. Soc. exp. Biol. Med. 75, 455.

Rosenblum, L. A., Nathan, T., Nelson, J. \& Kaufman, I. C. (1967) Vaginal cornification cycles in the squirrel monkey (Saimiri sciurea). Folia primatol. $6,83$.

Simpson, M. E. \& van Wagenen, G. (1957) Experimental induction of ovulation in the Macaque monkey. Fert. Steril. 9, 386.

Simpson, M. E. \& VAN WAGENEN, G. (1962) Induction of ovulation with human urinary gonadotrophins in the monkey. Fert. Steril. 13, 140.

van Wagenen, G. (1968) Induction of ovulation in Macaca mulatta. Fert. Steril. 19, 15.

van Wagenen, G. \& Cole, H. H. (1938) Failure of continued injections of gonadotrophic hormones to prevent menstrual cycles and pregnancy in Macaca mulatta. Am. F. Physiol. 123, 208.

van Wagenen, G. \& Simpson, M. E. (1957a) Induction of multiple ovulation in the rhesus monkey (Macaca mulatta). Endocrinology, 61, 316.

van Wagenen, G. \& Simpson, M. E. (1957b) Experimentally induced ovulation in the rhesus monkey (Macaca mulatta). Revue suisse Zool. 64, 807.

WAN, L. S. \& Balin, H. (1969) Induction of ovulation in rhesus monkeys: a comparative study. Fert. Steril. 20, 111 . 